\begin{tabular}{|l|c|c|c|r|}
\hline $\begin{array}{l}\text { Cuadernos de Investigación Geográfica } \\
\text { Geographical Research Letters }\end{array}$ & 2018 & No $^{\circ} 44(2)$ & pp. 601-614 & $\begin{array}{r}\text { ISSN 0211-6820 } \\
\text { eISSN 1697-9540 }\end{array}$ \\
\hline
\end{tabular}

\title{
STATUS AND PERSPECTIVES OF HYDROLOGICAL RESEARCH IN SMALL BASINS IN EUROPE
}

\author{
H. HOLZMANN \\ Dept. of Water, Atmosphere and Environment, \\ University of Natural Resources and Life Sciences, \\ Vienna, Austria.
}

\begin{abstract}
There is an uncontradicted consensus that experimental basin research plays an important role for the understanding of hydrological processes. Based on this, deepened knowledge concepts and hydrological models have been developed, which enable and support water management planning and decision making in all facets of hydrologically driven aspects like floods, climate change impact and environmental research. The following paper starts with a brief introduction to the history of hydrological monitoring and the initiation of hydrological research based on experimental watersheds. It highlights the international activities promoting and disseminating these kind of field research. Due to the personal involvement of the author, a special focus is given to the activities of the Euro-Mediterranean Network of Experimental and Representative Basins ERB and on the recent experimental basins inventory in Austria. As collection and provision of data form an important prerequisite for any further hydrological assessment, it is proposed that data sets and their providers in charge have to be cited and acknowledged in the research papers. These citations should gain the equivalent evaluation and ranking of paper citations and could stimulate the willingness for data provision. As a conclusion it can be stated that experimental basin research is carried out worldwide, but there is a lack of international communication among the stakeholders. A future development should therefore strengthen the communication platforms and foster extended data exchange.
\end{abstract}

\section{Estado y perspectivas de la investigación hidrológica en pequeñas cuencas en Europa}

RESUMEN. Existe un incontestable consenso en que las cuencas experimentales desempeñan un papel importante en el estudio de los procesos hidrológicos. Así, se ha profundizado en conceptos teóricos y se han desarrollado modelos hidrológicos que han permitido y apoyado la planificación y gestión de los recursos hídricos así como la toma de decisión en aspectos relacionados con avenidas, cambio climático e investigación medioambiental. Este artículo empieza con una 
breve introducción a la historia de la monitorización hidrológica y al comienzo de los estudios hidrológicos basados en cuencas experimentales, y destaca las actividades internacionales llevadas a cabo para fomentar y diseminar ese tipo de aproximación. Debido a la implicación personal del autor, se hace especial hincapié en las actividades de la "Euro-Mediterranean Network of Experimental and Representative Basins ERB" y al reciente inventario de cuencas experimentales llevado a cabo en Austria. Puesto que la recogida y suministro de datos constituyen un requisito importante para cualquier valoración hidrológica, se propone que datos y proveedores deben ser citados y agradecidos en las publicaciones científicas. Estas citas deberían tener una evaluación y ranking equivalente al de las citas de los artículos y podrían alentar así una disposición positiva al suministro de datos. A modo de conclusión, puede afirmarse que los estudios en cuencas experimentales se llevan a cabo en todo el mundo, pero existe una falta de comunicación internacional entre las partes interesadas. En el futuro se deberían reforzar las plataformas de comunicación y promover el intercambio extenso de datos.

Key words: experimental basin, hydrological research, hydrological monitoring, hydrological data.

Palabras clave: cuenca experimental, investigación hidrológica, monitorización hidrológica, datos hidrológicos.

Received: 2 September 2017

Accepted: 3 November 2017

* Corresponding author: Hubert Holzmann, Dept. of Water, Atmosphere and Environment, University of Natural Resources and Life Sciences. Muthgasse 18, A-1190 Vienna, Austria. E-mail address: hubert.holzmann@boku.ac.at

\section{Introduction}

\subsection{General}

Hydrological sciences generally deal with the assessment, analysis and interpretation of water balance components, the processes of water transport within the critical zone, and the interrelation between the regolith, biosphere, hydrosphere and atmosphere. Furthermore aquatic ecosystems, their functioning and relation to water status in quantitative and qualitative terms are of major concern in the frame of hydrological research. The knowledge about the hydrological components, their spatial and temporal evolution and their interrelation to climate change expectations are some of the manifold questions that arise in hydrological studies and can be supportively described my means of process observations and assessment in small experimental basins. The collection of real world data and time series of hydrological variables fosters and enables the quantification of behavioural information like means, extremes, frequencies and trends. Based on this knowledge, coherent decision making and environmental planning with 
respect to water management issues like flood protection strategies, irrigation demand, ecosystem services and future impact assessment can be achieved.

First activities in the assessment of water transport processes have already been done in the ancient cultures of Mesopotamia, Ancient Egypt, Greece and Rome. One outstanding example are the "nilometers" to observe the water levels of the Nile River. These concepts are described in Garbrecht (1985) but these ancient measurement activities will not furthermore be commented in the current paper. The first hydro-meteorological observations in the new age were mainly driven by the attempt to quantify the main water balance components like rainfall, evapotranspiration and runoff, and to support the newly developed physical concepts of hydrology and hydrodynamics.

\subsection{Development and objectives of standard observation networks}

The first continuous rainfall observations in Europe were carried out by scientific institutions or monasteries. The oldest rain gauge is located in the Netherlands in Zwanenburg where the data series started in 1735 and were continued in close Hoofddorp since 1881 (Buishand, 1977). Buishand (1977) used this data for statistical analyses but also mentioned the problem of homogeneity in the analysis of long rainfall data series. For the applied data series 1735-1972 he identified several potential causes for inhomogeneities like change of gauge height, change of collecting orifice, change of gauge type, etc. In Austria, standard rainfall observations started in 1791 in the monastery of Kremsmünster and the state network was established in 1893 by founding the Central Institute for Hydrography. This period of network instalments corresponds to the establishment of national hydro-meteorological observation networks elsewhere in Europe. Complementary to the installed rain observation network in those days, the responsible state institutions established discharge gauges and further monitoring equipment for meteorological variables like air temperature, humidity and wind velocity and directions. These data enabled the first application of water balance assessment in its spatio-temporal domain.

The purpose of the data monitoring and collection was generally to quantify the water balance components for further water management planning and to analyse, store and publish the key data in appropriate format as e.g. yearbooks. The focus of the data application was navigation, flood protection, hydropower and (drinking) water supply. In the last decades the study of environmental topics like water quality issues, sediment and debris load, irrigation demand or climate change impact increased its importance. The latter requires long, homogenous time series to identify significant trends and changes in process behaviour. Therefore we can consider long data series of hydrometeorological variables as a "valuable treasure" for scientific research and planning activities. It is important to notice that easy access to the data should be enabled for the scientific community and other users. In Austria, free data access of environmental data is guaranteed by the Austrian Water Right Act 2003 and its predecessor, the Austrian Hydrography Act 1979. Godina (2000) shows the number of the hydro-meteorological gauging stations in Austria (Table 1), which might represent the European level of density of the observation network. 
Table 1. Number of gauging stations in Austria (from Godina, 2000).

\begin{tabular}{|l|l|l|l|l|l|}
\hline variable & number & variable & number & variable & number \\
\hline rainfall & 1250 & water level & 760 & groundwater table & 2900 \\
snow depth & 900 & discharge & 545 & groundwater temp. & 350 \\
air temperature & 780 & water temperature & 210 & springs & 23 \\
\hline
\end{tabular}

But it is matter of fact that the operation and maintenance of the gauging stations is costly. Karner and Kugi (1998) estimated the annual costs for a single discharge gauge on approx. 3800 Euros, including personal wages, compensations, investment and maintenance costs (for 20 years). There is a global tendency to diminish gauging stations and to reduce the total number of observation gauges. Therefore it is important to convince the political decision makers of the huge value of long-term hydrological observations not only for scientific research but also for applied environmental planning.

\subsection{Scientific hydrologic field observations}

While the basic investigations of physics with respect to hydraulics and hydrodynamics were already invented before the second half of the $19^{\text {th }}$ century (Newton, Saint-Venant, Darcy) the more applied science of water transport processes had its strong phase in the first half of the $20^{\text {th }}$ century. In this time model concepts of the particular sub-processes were developed. Sherman (1932) invented the general theory of runoff transformation in the unit hydrograph concept, Horton (1933), Philip (1957) and Green and Ampt (1911) developed theories of the infiltration process, and the US Soil Conservation Service published its well know concept of runoff abstraction as a function of land use and soil properties (see actual version in USDA-SCS, 1985). Most of these studies were based on analysis of small-scale field observations and the interrelations of input and predictor variables were quite empirical. Since the 60 s of the last century - supported by new computer technologies - the methods became more process and physically based. Liebscher and Mendel (2010) therefore distinguished between the "age of empirical hydrology" and the "age of system hydrology" with its transition in the middle of the last century. Some outstanding contributions in the field of hydrologic process research are reported in the IAHS-issues "Benchmark papers in hydrology" (e.g., Beven, 2006). For instance, the contribution of Hoover and Hursh (1943) introduce the term "subsurface-stormflow" and their findings were based on observations at the Coweeta experimental forest. The authors were highlighting the role of forests and topographic effects on the runoff formation and flood retention. Hewlett and Hibbert (1967) also used the Coweeta data to come up with the "variable" contributing area concept", which substituted the so far existing state of the art infiltration excess concept. Their research introduced the perception of subsurface flow processes like lateral flow and the contribution to the channel stormflow. Cappus (1960) used data from the small experimental basin D`Alrance in the Massif Central $\left(3.15 \mathrm{~km}^{2}\right)$ to analyse storm and base-flow behaviour in relation to the state conditions 
(moisture, land use, rain duration, etc.). He also realized the importance of different runoff contributing areas in the basin to runoff formation. Tsukamoto (1963) explicitly noted the role of experimental basins in the title of his contribution, where he analysed the retention capacity of forested soils. His findings led to similar retention functions which have been introduced in the SCS curve number concept but his research also considered the differentiation of different contributing areas. Keller (1988), who was one of the forefathers of the ERB network mentioned later, referred to the European activities in experimental basin research. He explicitly addressed the importance of the continuation of observation programs to gain long-term data series. Bonnell (1993) and McCulloch and Robinson (1998) specifically addressed the role of forest vegetation for runoff generation. Their contributions focussed on different scales (plot, hillslope, catchment) and aimed the deepening of the process understanding to enhance the concepts and algorithms of runoff modelling. Stähli et al. (2011) described an even longer data series based on the long-term observations in Emmental, Switzerland. In particular two small catchments (Sperbelgraben and Rappengraben) were monitored since the year 1903 and form a valuable data base for public access for time series and extreme event analysis.

Many of the cited authors did their research at small basin scale, whereas some others only dealt inside the hillslope domains. The author wants to highlight the following two contributions in hillslope hydrology, as these applied concepts are quite similar to own field research (see Holzmann and Sereinig, 1997), carried out in the 90s without knowing their previous experiments. Whipkey (1965) collected hillslope flow in a transect using trough systems in different depths. He recognized significant runoff contribution coming from non-Darcy flow in preferential pores where the patterns rely on the varying moisture conditions. Ragan (1968) used a comparable experimental design to measure subsurface runoff contributions. In his conclusion he figured out that the consideration of partial area runoff contribution is an important demand also for hydrological model concepts. One of his statements in this publication can still be used as a keynote sentence of field research principles and has still kept its validity: "When undertaking any field investigation, the research hydrologist must have a mathematical model that has sufficient logic to properly define the quantities with which he is concerned and it must have sufficient flexibility to be applied in nature. Further if a meaningful physical interpretation is to be derived from his result, the site chosen for investigation must have sufficient uniformity to allow the limited experimental data that it is possible to collect to be meaningful and representative of the dominant processes."

\section{Experimental basin research in Europe}

\subsection{UNESCO - IHP as a frame for basin research}

The above mentioned contributions indicate that activities in the field of experimental basins research have been carried out throughout the world in the last century. But these activities were not systematically analysed and reviewed to lead to a stringent level of knowledge in the field of experimental basin research and to develop further joint research strategies with clear focal perspectives. Such aims were envisaged by the UNESCO 
International Hydrological Decade (IHD) in 1965 and its successor the International Hydrological Programme (IHP) starting in 1975. These UNESCO programs generally are devoted to water research, water resources management and education, and capacity building. The scientific program of the Decade embraced all aspects of hydrology and took into account the great diversity in the quality and quantity of hydrologic information available in various countries. The IHD actions are documented in Nace (1969) and included the following items beside others:

- Standardization of instruments, observations, techniques and terminologies for the collection, compilation and reporting of data.

- Establishment of basic networks and improvement of existing networks, to provide fundamental data on hydrological systems varying in size from small watersheds to the world as a whole. These data are essential for rational water use and conservation.

- Research on hydrological systems in selected geological, geographical, topographical, and climatic environments, constituting what may be called "representative basins". Information obtained will have transfer value. That is, conclusions reached concerning one basin may be applicable to another similar basin that has not been studied.

- Systematic exchanges of information.

A subsequent report from Toebes and Ouryvaev (1970) also addressed representative and experimental basins. The guide comprises six chapters: the Introduction describes the aims of the publication and the purpose of representative and experimental basins within the larger framework of hydrological research. Chapter 2 gives the criteria for selecting sites and for organizing a network of basins. Chapter 3 deals with the organization and planning of observations according to the aims of the research being carried out on the basins. Chapter 4 contains descriptions of methods of observation and types of instruments. Chapter 5 gives a wide range of methods for data processing, synthesis, and preparation and Chapter 6 deals with analysis techniques and interpretation of the results obtained.

\subsection{Euro-Mediterranean Network of Experimental and Representative Basins (ERB)}

Besides IHP there exist so called cross cutting programs like UNESCO FRIEND (Flow Regimes from International Experimental and Network Data) and HELP (Hydrology for the Environment, Life, and Policy), or ERB also with a pronounced focus on experimental field monitoring. The ERB activities are described in more detail in the following section because the author is personally involved in this network as ERB international coordinator $(2012$ - 2016) and as the Austrian national ERB correspondent.

ERB, the Euro-Mediterranean Network of Experimental and Representative Basins, is an open association of European countries operating and managing well instrumented experimental and representative basins for hydrological and environmental research on 
a long term basis. The ERB network promotes the exchange of basin information and the cooperation in international programs as FRIEND, HELP and PUB (Predictions in Ungauged Basins). ERB started in 1986 with nine member countries and has currently expanded to 22 countries. Since its establishment, the ERB organizes biannual conferences to disseminate the results of hydrological research in small catchments. These activities are documented in the ERB homepage (ERB, 2013), where also links to the respective conference proceedings are provided.

The main objectives of ERB are listed below and are in line with the aim of the UNESCO International Hydrological Decade goals:

- To increase relationships between members, research teams, universities and basin managers, through exchanges of hydrological information, data, research methods, models, and to organise visits and biennial conferences;

- To enable joint studies of common interest;

- To make available and exchange data between research groups;

- To harmonize methods of data collection and processing.

The topics of the biennial conferences reflect the status and focus of experimental basin research in the phase from 1988 to the present (Table 2).

It can be seen that the topics moved from rather process oriented approaches (19881994), via water quality aspects (1998-2000), via multi- and interdisciplinary approaches (1996, 2002), via innovative model concepts (2006) towards hydrological changes and related extremes (2008 -2016). These trends and requirements in hydrological field research are also summarized in Holko et al. (2015).

It seems to be unequivocal that experimental basins have significant and valuable impact on understanding hydrological processes, assess temporal environmental system change or test and validate model concepts. Nevertheless, the operation requires pronounced resources and manpower and therefore several examples of diminishing basin research were evident in the past. As a consequence, in 2009 a workshop on the status and perspectives of hydrology in small basins was jointly organized by the Technical University Braunschweig and the National IHP/HWRP ${ }^{1}$ Committee of Germany to analyse the status and benefit of experimental basins and to come up with recommendations on how to proceed with experimental basins. Herrmann and Schumann (2010) summarized the outcome of the workshop. Furthermore an inventory of presently operated small hydrological research basins was introduced.

1. Hydrology and Water Resources Programme of the World Meteorological Organization. 
Table 2. ERB-conferences and topics.

\begin{tabular}{|c|c|c|}
\hline Year & Venue & Conference Topic \\
\hline 1988 & Perugia (Italy) & Erosion and sediment transport \\
\hline 1990 & $\begin{array}{l}\text { Wageningen (The } \\
\text { Netherlands) }\end{array}$ & Hydrological research basins and the environment \\
\hline 1994 & Barcelona (Spain) & $\begin{array}{l}\text { Assessment of hydrological temporal variability and } \\
\text { changes }\end{array}$ \\
\hline 1996 & Strasbourg (France) & Eco-hydrological processes in small basins \\
\hline 1998 & Liblice (Czech Republic) & $\begin{array}{l}\text { Catchment hydrological and biochemical processes in } \\
\text { the changing environment }\end{array}$ \\
\hline 2000 & Ghent (Belgium) & $\begin{array}{l}\text { Monitoring and modelling catchment water quantity and } \\
\text { quality }\end{array}$ \\
\hline 2002 & $\begin{array}{l}\text { Demanovska dolina } \\
\text { (Slovakia) }\end{array}$ & Interdisciplinary approaches in small catchments \\
\hline 2004 & Torino (Italy) & $\begin{array}{l}\text { Progress in surface and subsurface water studies at the } \\
\text { plot and small basin scale }\end{array}$ \\
\hline 2006 & Luxembourg (Luxembourg) & $\begin{array}{l}\text { Uncertainties in the monitoring-conceptualisation- } \\
\text { modelling sequence of catchment research }\end{array}$ \\
\hline 2008 & Krakow (Poland) & Extreme hydrological events in small basins \\
\hline 2010 & Seggau Castle (Austria ) & $\begin{array}{l}\text { Hydrological Responses of Small Basins to a Changing } \\
\text { Environment }\end{array}$ \\
\hline 2012 & St. Petersburg (Russia) & $\begin{array}{l}\text { Studies of Hydrological Processes in Research Basins. } \\
\text { Current Challenges and Prospects }\end{array}$ \\
\hline 2014 & Coimbra (Portugal) & $\begin{array}{l}\text { Advances in Hydrologic Research on Pristine, Rural and } \\
\text { Urban Small Basins }\end{array}$ \\
\hline 2016 & Bucharest (Romania) & $\begin{array}{l}\text { Hydrological behaviour in small basins under changing } \\
\text { conditions }\end{array}$ \\
\hline 2018 & Darmstadt (Germany) & $\begin{array}{l}\text { New monitoring techniques and innovative modelling } \\
\text { approaches for analysing hydrological processes in small } \\
\text { basins }\end{array}$ \\
\hline
\end{tabular}

During this workshop the participants addressed issues and questions like (1) which achievements are expected from research in small basins in the coming decades; (2) how can small basin research contribute to the monitoring and understanding of changes in physical processes, water fluxes, water balance and global warming effects; (3) do we need research results from small basins for the further development of hydrological models? Beven (2010) contributed to the latter question and concluded that the track for model development (perception, conception, coding, calibration and evaluation) has to be cross-validated with respect to data and parameter limitations to deal both with epistemic and aleatory errors. An important outcome of the workshop was the "Braunschweig Declaration" (2009) on the need for a global network of long-term small 
hydrological research basins reported in Schumann et al. (2010), which concludes with the importance of experimental basins. The key message of the declaration are as follows:

a) Strengthening of existing networks in a cooperative endeavour to ensure longterm observations in a wide range of hydrological and environmental settings;

b) Creation of a global institutional framework for better recognition and support of networked small research basins;

c) Use of the global network as a set of representative and reference basins, providing long-term observatories;

d) Use of the networked observatories for active interdisciplinary process and modelling studies, as well as for education and training;

e) Adoption and support of the global network at the international level; and

f) Support for existing and, where appropriate, new hydrological research basins at the national level in order to contribute to the global network.

The biggest challenge in the development of a global network will be the creation of a joint user platform with information on the location, characteristics, responsibilities and data structure of a basin as a minimum requirement. Full data provision with standardized data format can rather be seen as a future perspective that will be hard to be achieved. First attempts have been carried out at the European level by the EUROFRIEND activity (see Schumann et al., 2010). Experimental basins of 18 countries are listed with summarized description for each basin in a poster format. This information can also be found online in the web-page of FRIEND-programme (see EURO-FRIEND, 2010).

Comparable structures and platforms have already been developed in the frame of ecosystem research. The LTER (Long Term Ecological Research) initiative has grown to a global initiative with regional groups, where the European LTER-Europe took over a leading role. Fourty-five national networks for long-term ecological research have joined together to encompass the most diverse types of ecosystems (forest, grassland, cities, etc.) across all climate zones and form a unique long term data system (Mirtl et al., 2010). The provision of metadata from more than 400 LTER-sites is made available via internet access (see www.lter-europe.net), so the network fosters the interaction and communication among the member groups.

\section{Experimental basin research in Austria}

As stated above it can be considered as a valuable goal to foster the publication of international experimental sites of Europe. As a first step, an inventory of existing hydrological experimental watersheds at a national level has to be achieved. This has recently been initiated in Austria under the responsibility of the Austrian Hydrological Society and the national ERB-committee. Research institutions active in hydrological field research have been invited to submit short descriptions (posters) of their field measurement activities with the aim to publish this information in 
the European network (e.g. EURO-FRIEND). The latter has still to be negotiated with the European platforms. Figure 1 shows the locations of existing and former hydrological experimental sites in Austria.

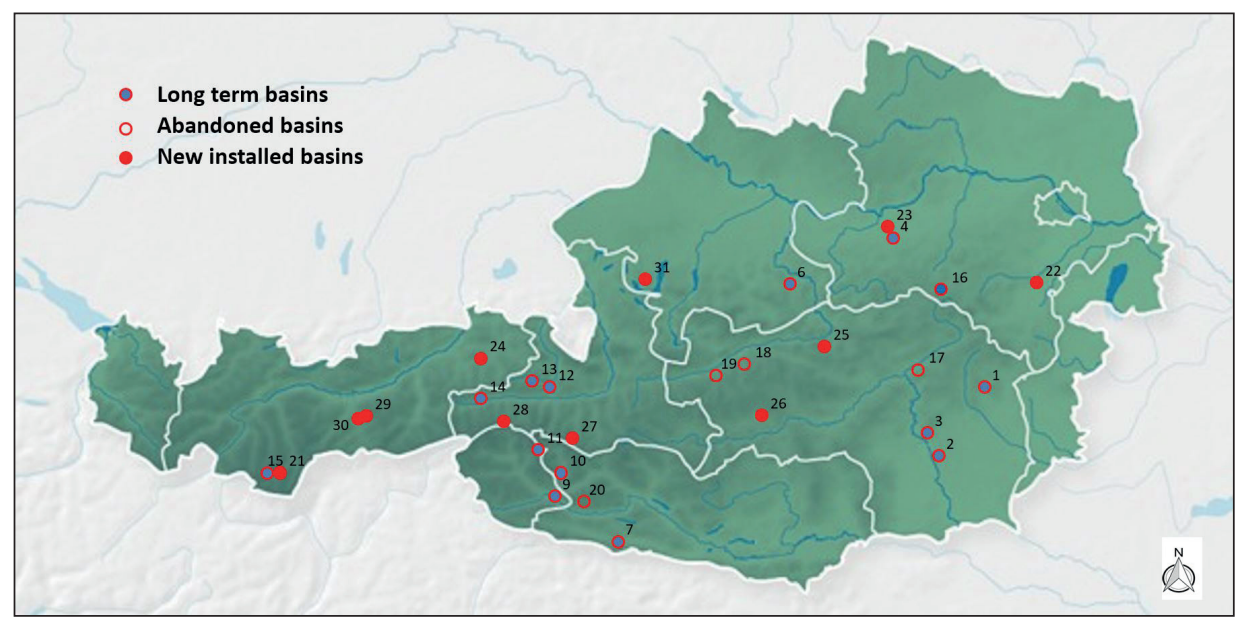

Figure 1. Location and status of experimental basins in Austria (from Müller and Holzmann, 2016).

Based on the first inventories from Nobilis et al. (2002), eleven new experimental sites have been established since then. This experimental research covers a broad range of hydrological topics dealing with processes in different environments like forest ecosystems, alpine pastures, glaciers, torrential basins, agricultural areas and lake systems. Table 3 describes, for each new site, the basin area, the hydrologic regime and the institution in charge.

The update of the experimental basins inventory provides information that is beneficial both for the hydrologic research community and the responsible operating institutions as well. The positive effects are as follows:

- Promoting the individual monitoring activities to the national and international community;

- Providing a summary of the Austrian activities;

- To become acquainted with innovative measurement techniques;

- Providing an interface for interdisciplinary activities;

- Demonstration of complementary observations from different branches.

In the ideal case, this inventory will stimulate bilateral contacts between institutions that may foster future cooperation and joint activities. General benefits of hydrological experimental basins for the deeper understanding of hydrological processes and interactions are addressed in Holko et al. (2015) or in Blöschl et al. (2016). 
Table 3. Newly installed basins in Austria.

\begin{tabular}{|c|l|l|l|l|}
\hline Nr. & Basin Name & Area $\left(\mathbf{k m}^{2}\right)$ & Hydrol. Regime & Institution \\
\hline 21 & Rofental & 98.1 & nivo-glacial & Uni Innsbruck \\
22 & Rosalia & 2.3 & nival & Uni BOKU \\
23 & HOAL Petzenkirchen & 0.66 & nival & TU Wien \\
24 & Brixenbach & 9.2 & nivo-pluvial & Uni Innsbruck \\
25 & Johnsbachtal & 65 & nivo-pluvial & Uni Graz \\
26 & Schoettlbach & 70.8 & nivo-pluvial & Uni Graz \\
27 & Rauriser Sonnblick & 2.8 & glacial & ZAMG \\
28 & Stubacher Sonnblick & 0.95 & glacial & HD Salzburg \\
29 & Lizumbach & 6.6 & nival & BFW Innsbruck \\
30 & Mölsbach & 13.5 & nival & BFW Innsbruck \\
31 & Mondsee & 248 & nivo-pluvial & Uni Salzburg \\
\hline
\end{tabular}

\section{Conclusions and future perspectives}

In the scientific hydrologic community there is an undeniable consensus that experimental basin research plays an important role for the understanding of hydrological processes. Due to the new demands in climate change research and environmental impact studies, long observation series are in particular of high relevance and value. Consequently, experimental research activities should strengthen and expand; in practise, however, they are threatened by the lack of financial support and misunderstanding of their importance by the decision makers. Many field activities are driven by immense commitment and enthusiasm of single units and persons, whose retirements often lead to the closure of the field activities.

Therefore it is of primary importance that all activities in hydrological field experiments are embedded in superordinate (national or transnational) information systems to enable the dissemination of the research output to the interested community and to foster the use and application of the particular data sets. As data collection and processing means a lot of effort, there is often the tendency of many scientists to hold back their data to enable its first and exclusive use. One further reason is also that so far data provision does not gain the correct and motivating recognition in the community. Therefore it has to be envisaged that data set and their providers in charge have to be cited and acknowledged in the consecutive research papers. These citations should gain the equivalent evaluation and ranking of paper citations. Such citation systems would help further research and assure reliable, predictable, and unambiguous access to research data in order to (a) support proper attribution and credit, (b) support collaboration and reuse of data, (c) enable reproducibility of findings, (d) foster faster and more efficient research progress, and (e) provide the means to share data with future researchers (Wilkinson et al., 2016). 
As a last conclusion of this paper, the following deals with the scale aspect of observation variables. Hydrological experimental research deepens the knowledge in process understanding by assessing state and response variables of the water balance and by comparing these values with computed results of hydrological models of different types. That means that the spatio-temporal scale of both the observation variables and the model components have to correspond with the real process scale. This prerequisite is often violated as the real processes are not always known. So new attempts have to be continued to apply new measurement and sensor techniques, which enable the assessment of state variable in the appropriate scale domain. Examples of innovative developments are remote sensing methods applying different thermal bands to interpret near surface state variables, or integrating sensors (e.g. scintillometers) to define lumped, average behaviour of respective sub-domains.

It can be concluded that hydrological experimental research has not lost anything of its importance and still has high capacity to gain more and innovative insight into the hydrological process research and its related sciences. The experimental research should be strengthened by improved information platforms on national and international levels that foster the communication among the research communities and the joint data use, enhancing the visibility of field research for stakeholders and decision makers.

\section{References}

Beven, K. 2006. Streamflow generation processes. Benchmark papers in Hydrology, IAHS, Wallingford.

Beven, K. 2010. Do we need research results from small basins for the further development of hydrological models? In: A. Herrmann, S. Schumann (Eds.), Proceedings of the international workshop on "status and perspectives of hydrology in small basins". IAHS Publication 336, pp. 279-285.

Blöschl, G., Blaschke, A.P., Broer, M., Bucher, C., Carr, G., Chen, X., Eder, A., Exner-Kittridge, M., Farnleitner, A., Flores-Orozco, A., Haas, P., Hogan, P., Kazemi Amiri, A., Oismüller, M., Parajka, J., Silasari, R., Stadler, P., Strauss, P., Vreugdenhil, M., Wagner, W., Zessner, M. 2016. The Hydrological Open Air Laboratory (HOAL) in Petzenkirchen: a hypothesis-driven observatory. Hydrology and Earth System Sciences 20, 227-255. http://doi.org/10.5194/hess20-227-2016.

Bonell, M. 1993. Progress in the understanding of runoff generation dynamics in forests. Journal of Hydrology 150, 217-275. https://doi.org/10.1016/0022-1694(93)90112-M.

Braunschweig Declaration. 2009. The need for a global network of long-term small hydrological research basins. https://iwhw.boku.ac.at/erb/Braunschweig_Declaration.pdf (last access: June 2009).

Buishand, T.A. 1977. Stochastic modelling of daily rainfall sequences. $\mathrm{PhD}$ thesis, Mededelingen Landbouwhogeschool Wageningen 77-3, Wageningen.

Cappus, P. 1960. Bassin expérimental d'Alrance. Étude des lois de l'écoulement. Application au calcul et à la prévision des débits. La Houille Blanche A, 493-520. https://doi.org/10.1051/ $\mathrm{lhb} / 1960007$.

ERB 2013. http://erb-network.simdif.com (Ed. Holzmann).

EURO-FRIEND 2010. Homepage of FRIEND initiative. http://ne-friend.bafg.de/servlet/is/17796/.

Garbrecht, G. 1985. Wasser, Vorrat, Bedarf und Nutzung in Geschichte und Gegenwart (Water, storage, demand and utilization in history and present), Rowohlt Verlag. 
Godina, R. 2000. Überblick über Daten und Datenarchive im Hydrographischen Dienst für Österreich (Summary of data and data archives of the Hydrological Survey of Austria). Wiener Mitteilungen Band 164.

Green, W.H., Ampt, G. 1911. Studies of soil physics, part I - the flow of air and water through soils. Journal of Agricultural Science 4, 1-24. https://doi.org/10.1017/S0021859600001441.

Herrmann, A., Schumann, S. 2010. Status and Perspectives of Hydrology in Small Basins. IAHS Publication 336, Wallingford.

Hewlett, J.D., Hibbert, A.R. 1967. Factors affecting the response of small watersheds to precipitation in humid areas. In: W.E. Sopper, H.W. Lull (Eds.), Forest hydrology, Pergamon Press, pp. 275-90.

Holko, L., Holzmann, H., De Lima, M.I.P., De Lima, J.L.M.P. 2015. Hydrological research in small catchments - an approach to improve knowledge on hydrological processes and global change impacts. Journal of Hydrology and Hydromechanics 63 (3), 181-182. http://doi. org/10.1515/johh-2015-0032.

Holzmann, H., Sereinig, N. 1997. In situ measurements of hillslope runoff components with different types of forest vegetation. In: A. Gustard, S. Blazkova, M. Brilly, S. Demuth, J. Dixon, H. van Lanen (Eds.), FRIEND'97 - Regional Hydrology. Concepts and Models for sustainable Water Resources Management. IAHS Publication 246 pp., 317-324.

Hoover, M.D., Hursh, C.R. 1943. Influence of topography and soil-depth on runoff from forest land. Transactions of the American Geophysical Union 24, 693-697. http://doi.org/10.1029/ TR024i002p00693.

Horton, R.E. 1933. The role of infiltration in the hydrologic cycle. Transactions of the American Geophysical Union 14, 446-460. http://doi.org/10.1029/TR014i001p00446.

Karner, C., Kugi, W. 1998. Kosten und Nutzen hydrographischer Daten (Cost benefit analysis of hydrographic data - Case studies of Austria). Fallbeispiele aus Österreich; Mitteilungsblatt des Hydrographischen Dienstes in Österreich Nr. 77.

Keller, H.M. 1988. European experiences in long-term forest hydrology research. In: W.T. Swank, D.A. Crossley Jr. (Eds.), Forest Hydrology and Ecology at Coweeta. Ecological Studies. Vol. 66, Springer-Verlag, pp. 407-414.

Liebscher, H.J., Mendel, H.G. 2010. Vom emprischen Modellansatz zum komplexen hydrologischen Flussgebietsmodell. Rückblick und Perspektiven (From empirical model concepts to complex hydrologic river basin models - review and perspectives). Bundesanstalt für Gewässerkunde Report, Koblenz.

McCulloch, J.S.G., Robinson, M. 1993. History of forest hydrology. Journal of Hydrology 150, 189-216. https://doi.org/10.1016/0022-1694(93)90111-L.

Mirtl, M. 2010. Introducing the Next Generation of Ecosystem Research in Europe: LTER-Europe's Multi-Functional and Multi-Scale Approach. In: F. Müller, C. Baessler, H. Schubert, S. Klotz (Eds.), Long-Term Ecological Research. Springer, Dordrecht. https://doi.org/10.1007/97890-481-8782-9_6.

Müller, G., Holzmann, H. 2016. Inventory of the experimental basins in Austria. Poster contribution to the ERB conference 2016 in Bucarest.

Nace, R.L. 1969. Water and man - a world view. The international hydrological decade. UNESCO series.

Nobilis, F., Bergmann H., Müller, G. 2002. Hydrologische Versuchsgebiete in Österreich. Mitteilungsblatt des Hydrografischen Dienstes in Österreich nr.81 (Hydrological test basins in Austria - Experiences and requirements. Report of the Austrian Hydrological Survey).

Philip, J.R. 1957. The theory of infiltration. 1. The infiltration equation and its solution. Soil Science 83, 354-357.

Ragan, R.M. 1968. An experimental investigation of partial area contribution. Hydrological aspects of the utilization of water, Reports and Discussions, IAHS Publication 76, pp. 241-251. 
Schumann, S., Schmalz, B., Meesenburg, H., Schröder, U. 2010. Status and Perspectives of Hydrology in Small Basins. Results of the International Workshop in Goslar-Hahnenklee, 2009 and Inventory of Small Hydrological Research Basins. IHP/HWRP-Berichte 10, Koblenz, Germany. http://www.euro-friend.de.

Sherman, L.K. 1932. Streamflow from rainfall by the unit hydrograph method. Engineering newsrecord 108, 501-505.

Stähli, M., Badoux, A., Ludwig, A., Steiner, K., Zappa, M. Hegg, Ch. 2011. One century of hydrological monitoring in two small catchments with different forest coverage. Environmental Monitoring and Assessment 174, 91-106. http://doi.org/10.1007/s10661-0101757-0.

Tsukamoto, Y. 1963. Storm Discharge from an Experimental Watershed. Journal of the Japanese Forestry Society 45 (6), 186-190. https://doi.org/10.11519/jjfs1953.45.6_186.

Toebes, C., Ouryvaev, V. 1970. Representative and experimental basins. UNESCO series.

USDA-SCS, 1985. National Engineering Handbook, Section 4, Hydrology. USDA-SCS, Washington, D.C.

Whipkey, R.Z. 1965. Subsurface stormflow from forested slopes. International Association Scientific Hydrology Bulletin 10, 74-85. http://doi.org/10.1080/02626666509493392.

Wilkinson, M.D., Dumontier, M., Aalbersberg, I.J., Appleton, G., Axton, M., Baak, A., Blomberg, N., Boiten, J.W., da Silva Santos, L.B., Bourne, P.E., Bouwman, J., Brookes, A.J., Clark, T., Crosas, M., Dillo, I., Dumon, O., Edmunds, S., Evelo, C.T., Finkers, R., Gonzalez-Beltran, A., Gray, A.J.G., Groth, P., Goble, C., Grethe, J.S., Heringa, J., Hoen, P.A.C't, Hooft, R., Kuhn, T., Kok, R., Kok, J., Lusher, S.J., Martone, M.E., Mons, A., Packer, A.L., Persson, B., Rocca-Serra, P., Roos, M., van Schaik, R., Sansone, S.A., Schultes, E., Sengstag, T., Slater, T., Strawn, G., Swertz, M.A., Thompson, M., van der Lei, J., van Mulligen, E., Velterop, J., Waagmeester, A., Wittenburg, P., Wolstencroft, K., Zhao, J., Mons, B. 2016. The FAIR Guiding Principles for scientific data management and stewardship. Scientifc Data 3, 160018. https://doi.org/10.1038/sdata.2016.18. 